\title{
Rubratoxin B induces apoptosis in p53-null cells
}

\author{
Hitoshi NAGASHIMA*1, Yasuki IshIZAKI*2, Masamichi NishidA*2, Ikuo MoriTA*2, \\ Sei-itsu Murota*2 and Tetsuhisa Goto*1
}

(Received June. 4, 1997 ; Accepted Sept. 18, 1997)
長嶋等*1, 石崎 泰樹*2, 西田 昌道*2, 森田 育男*2, 室田 誠逸*2, 後藤 哲久*1 : ルブラトキシン B は p53 欠損細胞にアポトーシスを誘導する

\begin{abstract}
Summary
Exposure to rubratoxin B caused homozygous null p53 cells to shrink, condense their chromosomes and fragment their nuclei, showing that rubratoxin B induces apoptosis in p53-null cells
\end{abstract}

Key words : rubratoxin B, ルブラトキシン B ; apoptosis, アポトーシス ; p53, p53

\section{Introduction}

Rubratoxin $\mathrm{B}$ is a potent hepatotoxic ${ }^{1,2)}$ and teratogenic $^{3,4)}$ mycotoxin produced by the fungi Penicillium rubrum and Penicillium purpurogenum ${ }^{1,5)}$. We previously reported that rubratoxin $B$ induced internucleosomal fragmentation (DNA ladder) ${ }^{6}$ and brought about nuclear fragmentation ${ }^{6}$, suggesting that the toxicity of rubratoxin $B$ is the consequence of apoptosis ${ }^{6,7)}$. To date, p53-dependent ${ }^{8,9)}$ and independent $^{10,11)}$ apoptosis have been reported. The p53 tumor suppressor protein preserves genetic stability by mediating either a $G_{1} \operatorname{arrest}^{12,13)}$ or apoptosis $^{8,10)}$ in response to DNA damage. In this report, to elucidate the mechanism of apoptosis induced by rubratoxin $B$, we investigated p53dependency using homozygous null p53 cells.

\section{Materials and Methods}

Chemicals and cells Rubratoxin B was purchased from Makor Chemicals (Israel). Cultured homozygous null $p 53$ mouse embryo fibroblast cell (p53null cell $)^{10)}$ was generously given by Dr. A. Fanidi.
The p53-null cell was cultured in Dulbecco's Modified Eagles medium containing $10 \%$ fetal calf serum.

Morphological study Four times $10^{5}$ cells in $2 \mathrm{ml}$ of medium with rubratoxin $B$ were cultured in each well of a 6 -well plate for $24 \mathrm{hr}$, followed by microscopic examination. For examination of nuclei, $4 \times$ $10^{5}$ cells in $2 \mathrm{ml}$ of medium with $10 \mu \mathrm{g} / \mathrm{ml}$ rubratoxin $\mathrm{B}$ were cultured in a glass bottom cuture dish for 24 $\mathrm{hr}$, then stained with $5 \mu \mathrm{g} / \mathrm{ml}$ Hoechst 33258 at $37^{\circ} \mathrm{C}$ for $30 \mathrm{~min}^{14)}$. The nuclei were examined by fluorescence microscopy.

\section{Results and Discussion}

As shown in Fig. 1, exposure to rubratoxin B caused p53-null cells to shrink, similar to the results of other cultured cells ${ }^{7,15)}$. Seeing that more than half of the cells floated after the $24 \mathrm{hr}$-treatment of 40 $\mu \mathrm{g} / \mathrm{ml}$ of rubratoxin B (Fig. 1C), p53-null cells are more sensitive than HeLa and HepG2 cells which did not float under the same experimental condition ${ }^{7}$. Since shrinkage of the cells is one of the characteristics of apoptosis, our results suggested the possibility that rubratoxin $\mathrm{B}$ induces apoptosis in p53-null cells.

${ }^{* 1}$ National Food Research Institute, Ministry of Agriculture Forestry and Fisheries, 2-1-2 Kannondai, Tsukuba, Ibaraki 305, Japan

農林水産省食品総合研究所（テ305 つくば市観音台 2-1-2）

*2 Graduate School, Tokyo Medical and Dental University, 1-5-45 Yushima, Bunkyo, Tokyo 113, Japan 東京医科歯科大学大学院（下113 東京都文京区湯島 1-5-45） 


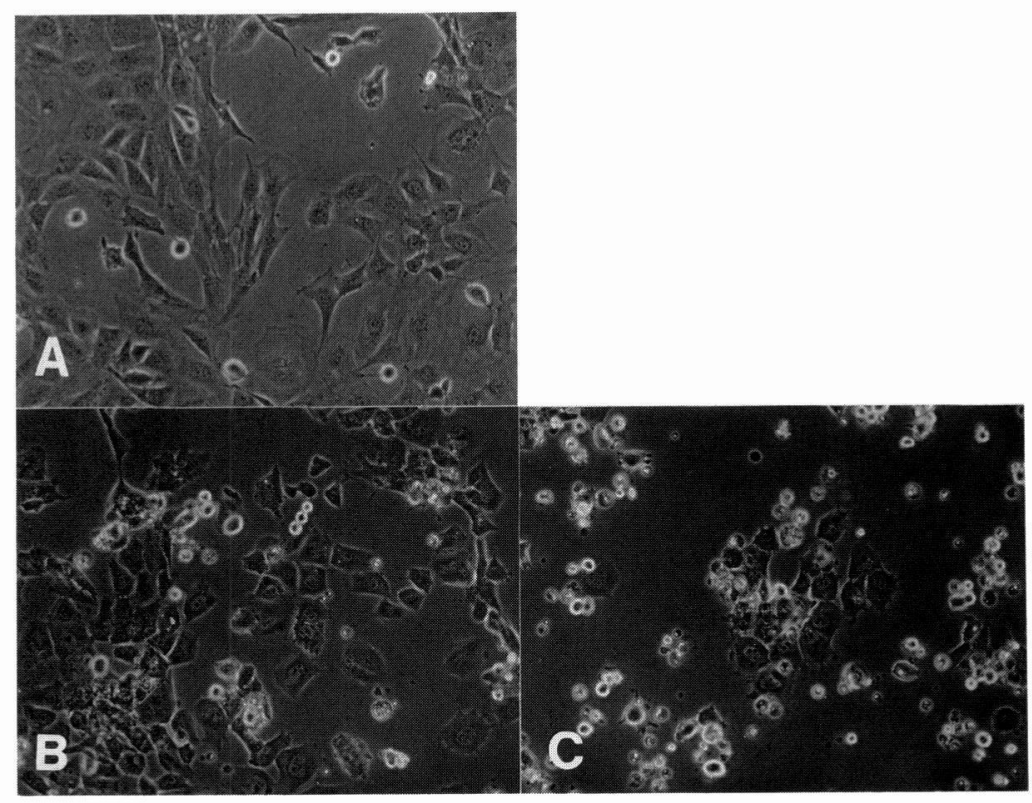

Fig. 1 Morphological change of p53-null cells by rubratoxin B. (A), Control ; (B), treated with $20 \mu \mathrm{g} /$ $\mathrm{ml}$; (C), treated with $40 \mu \mathrm{g} / \mathrm{ml}$ of rubratoxin B for $24 \mathrm{hr}$. (Magnification $\times 100$ )

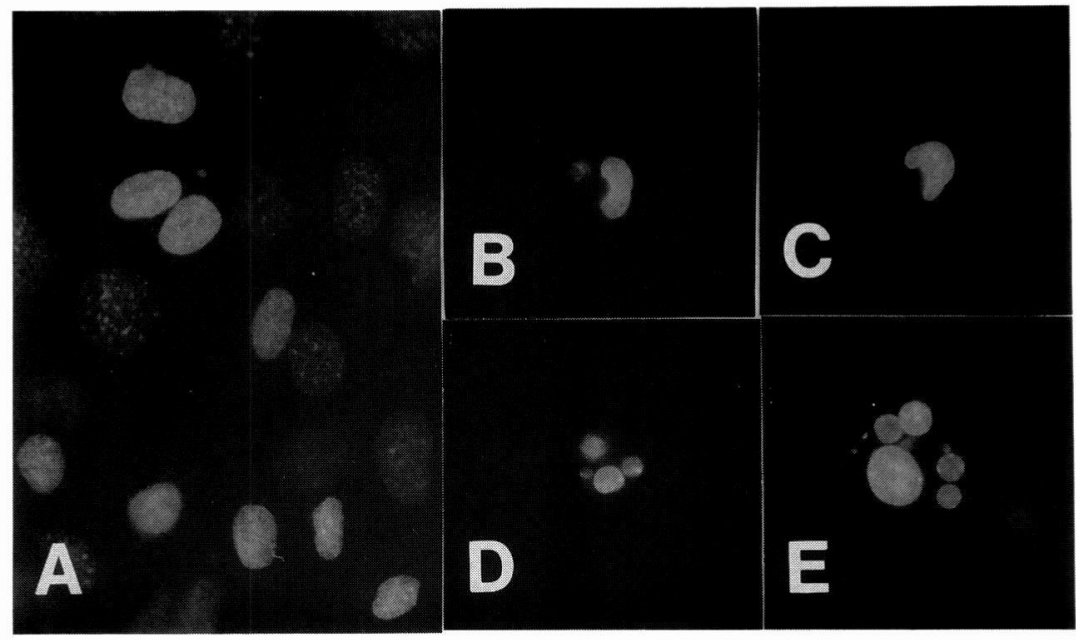

Flg. 2 Morphological change of p53-null cell nuclei by rubratoxin B. (A), Control ; (B-E), treated with $10 \mu \mathrm{g} / \mathrm{ml}$ of rubratoxin B for $24 \mathrm{hr}$. The cells were stained with Hoechst 33258, then the nuclei were examined by fluorescence microscopy (Magnification $\times 400$ )

To confirm that the shrinkage of the cells was the consequence of apoptosis, we investigated the morphological change of nuclei induced by rubratoxin $B$, since the condensation of chromatin and nuclear fragmentation are the typical morphological changes of apoptosis ${ }^{16)}$. Compared to the control (Fig. 2A), rubratoxin B-treated chromatins were condensed (Fig. 2B-2E). Furthermore, we observed crescents 
in apposition to the nuclear membrane (Fig. 2B, 2C), and several dense spheres (Fig. 2D, 2E) as a result of nuclear fragmentation. Therefore, our results showed that rubratoxin B induced apoptosis in p53null cells. Although these changes are often accompanied by DNA ladder, we could not detect under these experimental conditions (data not shown), as in the case of HeLa cells ${ }^{6)}$.

Rubratoxin B induced apoptosis in HL-60 cells ${ }^{6)}$. The p53 protein and mRNA were not detected in HL-60 cells, probably because of major deletions in the coding region of $p 53$ gene $^{17)}$. Inasmuch as rubratoxin B induces apoptosis in two independent p53-deficient cell lines, our results strongly suggest that rubratoxin $\mathrm{B}$ can induce p53-independent apoptosis. There is a possibility, however, that the activity of p53 in HL-60 cells is not completely lost. HL-60 cells retain the $5^{\prime}$ part of $p 53$ gene $^{17)}$, and only the first 214 amino-terminal residues of murine p53 was sufficient to induce p53-dependent apoptosis ${ }^{18)}$. Further studies are needed to clarify whether rubratoxin $\mathrm{B}$ induces apoptosis exclusively mediating p53-independent pathway or not.

Acknowledgement We wish to thank Dr. A. Fanidi for his generous gift of cell.

\section{References and Notes}

1) Natori, S., Sakaki, S., Kurata, H., Udagawa, S., Ichinoe, M. Saito M., Umeda, M., Ohtsubo, K. : Appl. Microbiol. 19, 613 (1970).

2) Burnside, J. E., Sippel, W. L., Forgas, J., Caroll, W. J., Atwood, M. B., Doll, E. R. : Amer. J. Vet.
Res., 18, 817 (1957).

3) Hood, R. D., Innes, J. E., Hayes, A. W.: Bull. Environ. Contam. Toxicol., 10, 200 (1973).

4) Koshakji, R. P., Wilson, B. J., Harbison, R. D.: Res. Commun. Chem. Pathol. Pharmacol., 5, 584 (1973).

5) Wilson, B. J., Harbison, R. D. : J. Amer. Vet. Med. Assoc., 163, 1274 (1973).

6) Nagashima, H., Goto, T. : Mycotoxins, No. 46, 17 (1998).

7) Nagashima. H, : Mycotoxins, 42, 57 (1996).

8) Lowe, S. W., Schmitt, E. M., Smith, S. W., Osborne, B. A., Jacks, T.: Națure, 362, 847 (1993).

9) Yonish-Rouach, E., Grunwald, D., Wilder, S., Kimchi, A., May, E., Lawrence, J.-J., May, P., Oren, M. : Mol. Cell. Biol., 13, 1415 (1993).

10) Clarke, A. R., Purdie, C. A., Harrison, D. J., Morris, R. G., Bird, C. C., Hopper, M. L., Wyllie, A. H. : Nature, 362, 849 (1993).

11) Allday, M. J., Inman, G. J., Crawford, D. H., Farrell, P. J. : EMBO J., 14, 4994 (1995).

12) Kastan, M. B., Onyekwere, O., Sindransky, D., Vogelstein, B., Craig, R. W.: Cancer Res., 51, 6304 (1991).

13) Kuerbitz, S. J., Plunkett, B. S., Walsh, W. V., Kastan, M. B. : Proc. Natl. Acad. Sci. USA, 89, 7941 (1992).

14) Jacobson, M. D., Burne, J. F., Raff, M. C.: EMBO J., 13, 1899 (1994).

15) Nagashima, H., Nishida, M., Ishizaki, Y., Morita, I., Murota, S., Goto, T. : “Animal Cell Technology : Basic \& Applied Aspects, Vol. 8” p. 571 (1997), Kluwer Academic Publishers, Dordrecht.

16) Cohen, J. J. : Immunol. Today, 14, 126 (1993).

17) Wolf, D., Rotter, V.: Proc. Natl. Acad. Sci. USA, 82, 790 (1985).

18) Haupt, Y., Rowan, S., Shaulian, E., Vousden, K. H., Oren, M. : Genes Dev., 9, 2170 (1995). 